Academic Voices

A Multidisciplinary Journal

Volume 6, N0. 1, 2016

ISSN 2091-1106

\title{
PUBLIC PARTICIPATION IN GOVERNANCE OF COMMUNITY COLLEGE
}

\author{
Ram Babu Mandal \\ Department of Foundation of Education, TU, Thakur Ram Multiple Campus, Birgunj, Nepal \\ Email: dearrambabu55@gmail.com
}

\begin{abstract}
The purpose of this study was to explored public parti tion in governance of the comm unity college. The local people established col heir community of their active participation. Community colleges help for the access of higher education in rural area but not being able to fulfill desire of the local people. The study focuses on public participation in governance of community college.The study was carried out in a qualitative paradigm in which a case study facilitated access to in-depth feelings, views, and opinions of community members and educators regarding their participation in providing e ucation. Data were generated through in-depth interview with parents of children in the college, CollegeManagement Committee (CMC) members, and the col chief. Data were transcribed and analyzed manually through the cut and paste technique. The study found out that public participation in governance of community colleges is of various types it may be involvement through sending their children to the college and providing fees and stationery, involvement through contributions of physical things \& donations from the beginning of the establishment of the college, involvement through atte dance in programs and meetings conducted by the college, participation in real decision making etc. Further, parents financed college budgets, and were involved in college governance
\end{abstract}

\section{Ke y words}

Community participation; community impact; teaching and learning; governance

\section{Background of the study}

The colleges established under public investment, locally generated fund \& resources, more participation of local people, and governed and managed by college management committee are called community colleges. Local community established collegein their community of their active participation. Community colleges help for the access of higher education in rural area but not being able to fulfill desire of the local 
people. The college uses the infrastructure and other facilities of secondary school of their community at the beginning of college. But the resource management of community college must be responsibility of local people. In this context, this study focuses on public participation in governance of community college.

\section{Higher education in Nepal}

Higher education in Nepal started with the establishment of Trichandra College in 1918. The college followed the courses of Patina university of India and the teachers al so came from India. The examination were conducted and result published by the Patna university. In 1959, Tribhuvan University was established in N epal. After theestablishment of Tribhuvan University both the government colleges and community managed colleges got affiliated to Tribhuvan University. The NESP (1971-75) was introduced and all the community colleges are nationalized and brought directly under the Tribhuvan University. The higher education commission (1980) brought major changes in the higher education that is multi university concept and private and community colleges (Bhusal, 2013).

There are three types of colleges running under the Tribhuvan University: Constituent College, Community College and Private College on the basis of their funding for their operation. Tribhuvan University itself conducts and regulates the constituent colleges. It provides the funds, manages human resources as well as physical resources. There are 60 constituent colleges, 638 Private colleges and 425 community colleges are established under the rules and regulations of Tribhuvan University (UGC, 2016). The fees and other facilities of private colleges are set by itself. The fees are found to be higher of private college compared to the community and constituent colleges. The colleges established under public investment, locally generated fund \& resources, more participation of local people, and governed and managed by college management committee are called community colleges. There are 425 Community Colleges running under the Tribhuvan University. According to the UGC (2016) thereare 561colleges have less than 100 students and 801 colleges have less than 200 students. The university provides the affiliation to community colleges but there is lacking the continuous monitoring $\&$ supervision.

\section{Community participation}

Community participation means involvement of people with similar needs and goals. Aref (2010) explored theroles of communities in the development of education. The participation of community is issue of global concern. The developed countries communities have already overcome the preliminary issues so the important role in the processes of educational planning and development are significant. But in third world countries that are suffering from the basic issues like low budget, poor infrastructure, low income etc. are in face of community participation in education activities. According to Shaeffer (1994) the participation are of different forms or levels, including: involvement by contributing materials, money, and labor. In this level participants provide either money or other necessary materials for construction and similar other purposes or provides the working manpower or self-efforts. In the level attendance, participants involve themselves in different fomal programs like parents' meetings at school, school visit etc. and imply passive acceptance of decisions made by others. The next level is involvement through consultation on a particular issue like school level upgrade, recruitment of staffs; new construction works etc. Participants can involve them through involvement in the delivery of a service, like providing trainings to teachers, providing transportation for tours and educational excursions etc. The last one is the level of participation in which participants involve themselves as implementers of delegated powers; and 
participation in real decision at every stage, including identification of problems, the stage of planning, implementation, and evaluation.

Abbass (201) describes that in the promotion and management of education as well as community capacity development communities can be involved. Communities play different vital roles in the enhancement of democratic practice and stability of college education. The participation of community in education and democratic participation must be inherently connected to each other for stable organization and good governance of educational institutions. Community participation in educational development processes can support and uphold local culture, tradition, knowledge and skill, and createpridein community heritage.

Adam (2005) reached the conclusion in his study that school performance or progress cannot be explained by only the community participation but other variables come into play in explaining performance. The other variables may be the natural disasters and other factors, political instability, geographical condition etc. However, where community pays active participation, there would be better performance. Also, the study states that participation and the forms it takes depend on a number of factors. And that performance and participation influence each other and depend on each other. Rich well-resourced and willing communities always can have the potential of ensuring better performance of schools. This can result in inequality in the rate of development of schools.Godfrey (2016) describe that communities are involved in providing primary education through making students able to attend the school through different efforts like proving them foods, purchasing the uniforms and providing the stationery. Besides these they also get involved in completing the home works. Also the parents prepare the school for children by providing labor and construction materials. And also parents support the school budgets, and were involved in school governance.
Besides these, thing there challenges too for the community colleges. These are parents low standard of living, community attitude towards education, family income level, and school-community relations. In the study of Emmanuel, Quansah \& Debrah (2015) they have mentioned about several approaches that a government can adopt to reach the need of the community by using the local resources. Community involvement in the planning of infrastructures helps to mobilize or generate rich resources from both community and central government towards the implementation of projects. Community participation plays a vital role to ensure sustainability of the projects implemented as the communities play a key role or management role.

According to ADB (2015) the local community established and owns the community college. The college must accountableand transparent to the local people as it is a non-profit entity of the local community. The governed of this college perform by the local people under the published rulesand regulation. In context, the university only provides affiliation but does not support for further processes like faculty recruitment, infrastructure development, library management, budgeting etc. Thus local people must be more participative to manage resources, increase enrollment rate, maintain the proper infrastructures, plan proper budget, increase library facility etc. Communities can play a variety of roles in the provision and management of education and learning processes. Community participation can contribute to promoting education (UNICEF, 1994). Community participation is a concept that attempts to bring different stakeh olders together for problem solving and decision making. Community participation is considered necessary to get community support for educational planning and development. Community participation refers to peoples' engagement in activities within the educational system. It plays an essential and longstanding role in promoting quality of life. Community participation in educational 
development processes can support and uphold local culture, tradition, knowledge and skill, and create pride in community heritage. In my study I focus on what is the status of public participation in governance of the community college. The purpose of th is study is to explore the public participation in governance of the community college.

\section{Methods}

The research includes the philosophical ideas that are associated with non-positivistic research paradigm -interpretivism. Case study was adopted for public participation in governance of the community college. For collection of data one community college of Bara district was purposively selected and one parents, one College Management Committee (CMC) member, and college chief were selected for personal interviews. Data were transcribed and manually analyzed through reading and re-reading, comparing and contrasting, highlighting and coding, themes emerged as findings for the study.

\section{Results and discussion}

Community colleges are usually established and governance in the combined efforts of the local community. The local community are responsible for the managing the resources of the community college. Most of the community colleges established in the rural areas and the students enrolled in that college are also the children of rural people. The community colleges are running by fees of the students and support from the community as well as local government and non-government offices.

\section{Participating student facilities}

The study found out that communities were involved in providing college education through sending their children for college without any disturbance and involving in household work of them, paying the fees of the college and provided uniform, stationery and text books for their children. O ne of the community member said that "I can enroll my daughter in community campus because it is near of at my home if the campus is far from here I couldn't send her in urban area because of my low economic status." The parents and the community help in the establishment of the community colleges for the meets the needs, interest and the expectations of the local community. Community colleges have been providing education mainly middle and lower middle income groups of people. The community colleges charged substantial tuitions but the tuitions charge of private colleges arehigher (ADB, 2015). But according to campus chief 'there are some parents who assist the college but they send their children other than community college, which also creates problems.The UGC provided limited amount of grant fund to community colleges based on their number of students, numbers of program and the location of the college.

\section{Participating in construction of college facilities}

The community colleges are usually established in the combined efforts of the local community for the concept of decentral ization and access of higher education in rural area. The community members support the college before the establishment. The university provides the affiliation but further do not pay attention to the colleges regarding their operation and management. The responsibilities of operation remain in the management committee and the local community. The communities were also involved through preparing college for the children by providing land, money,labor and building materials for construction of facilities such as classrooms, playgrounds and toilets. In addition, communities were involved in providing funding for college budgets as well as participating in college governance. According to campus chief there are some parents who promised to provide money, land or other materials to college 
but they did not provide in time, that create problems in managing community college. In this context, Sharma (2008) found that parents do not themselves as having any defined responsibilities for the learning of their children and administrators ignore the fact that parents and community could play an important role in supporting quality education. Thus, parents' active participation can support to enhance the teaching learning environment in college.

\section{Participating in college meetings}

The community colleges are governed and managed by the College Management Committee base on their published rules and regulations. The active participation of community members formulate the College $M$ anagement Community for the running the daily activity of the college. The rule of a meeting of CMC is in the every two months but some-times two or three meeting happened in one month's, in this context, all the members of the CMC did not present in the CMC meeting. So that, the important agenda won't be discussed more deeply. The study found that the community college is running without the active participation of community members. The parents and community members have not seen in meaningful participation in annual program, parent's day and the other function of the college.

\section{Participating in monitoring college}

The universities are responsible for monitoring their affiliated institutions and academic programs. They monitor all their affiliated campuses through student enrollment and examination records. The campuses are required to pay affiliation fees to the universities, and to submit reports on student enrollment, programs activities, and examination results. The college must accountable and transparent to the local people as it is a non-profit entity of the local community. Community members have been monitoring college by presenting oneself. They monitor only inspecting way: did teacher present or not? The teachers involve fulltime of less than required time in the classroom. The study found that some community members observe the above questions and monitor the college. According to a college teacher some time community members observe class room teaching by watch th rough the window in the course of teaching and learning period. The relationship between local people and college is crucial to improve the performance of college. Sharma (2008) stress that active involvements of community in school management improve the quality of education.

\section{Conclusion}

Participation of the public in governance of community colleges is of various types it may be involvement through mere use of a service by sending their children to the college and providing the college uniform college fees, stationery and other materials, involvement through contributions of physical things \& donations of money and land from the very beginning of the establishment of the college, involvement through atten dance in programs and meetings conducted by the college, participation in real decision making etc. Some parents assist the college but they send their children other than community college, some community member did not provide land, money or other materials which they promised earlier.

\section{References}

Abbass, I. M . (2012). Community participation in education: Challenges and prospects in Nigeria's democracy. European Scientific Journal, 8(5) 110 . Retrieved from http:// eujournal.org/index.php/esj/article/ viewFile/8186

Adam, F. (2005). Community participation in school development: Understanding participation in basic schools performance 
in the Nanumba district of Ghana. The University of Bergen, Norway. Retrieved from http://dspace.uib.no/bitstream/ handle/ 1956/ 1145/ AD AM \%20THESIS. pdf ?sequence $=1$ \&isAllowed $=y$

Aref, A. (2010). Community participation for educational planning and development. Nature and Science, 8(9) 1-4.

Asian Development Bank (2015).Innovative strategies in higher education for accelerated human resource development in South Asia: Nepal. Philippines: Author.

Bhushal, B. (2013). Leadership influence on quality enhancement of community college (Unpublished M. Phil. dissertation). Kathmandu University, School of Education, Lalitpur, Nepal.

Centre for Economic Development and Administration (2007). Financing the higher education in Nepal. Kathmandu: Author.

Creswell, J.W. (2014). Research design: Qualitative, quantitative and mixed methods approach (4th eds.).Thousand Oaks. CA: Sage.

Creswell, J.W. \& Plano Clark, V. L. (2011). Designing and conducting mixed methods research (2nd Eds.). Thousand Oaks, CA: Sage.

Galami, T.B. (2004). Teachers' professional development in higher education (A case of $T U$ ) (Unpublished M. Phil.dessertaion). Kathmandu University, School of Education, Lalitpur, Nepal.
Godfrey, S.M. (2016). Challenges impacting community participation and their effect on teaching and learning: A case study of rural areas. European Scientific Joumal, 12(25) 345-364 doi: 10.19044/esj.2016. v12n25p345

Saeffer, S. (1994). Participation for educational change:A synthesis of experience, Paris, IIEP. Retrieved from http://unesdoc.unesco. org/images/ 0009/000992/099230E.pdf

Sharma, T.N. (2008). Structures and mechanisms of community Participation in school management.Journal of Education and Research 1(1), 72-86.

Shrestha, D.P. (2008). Management practices in the institution for higher education in Nepal (Unpublished M. Phil.dessertaion). Kathmandu University, School of Education, Lalitpur, Nepal.

Stake, R.E. (1995).The art of case study research: Perspectives and practice, Thousand Oaks, CA; Sage.

UNICEF. (1992). Strategies to promote girls' education: Policies and programs that work. New York: Author.

University Grants Commission (2016). Education management information system 2014/ 15. Bhakatpur: Author.

Wedam, E., Quansah, J.Y. D. \& Debrah, I.K. (2015).Community participation in educational infrastructure development and management in Ghana.Education, 5(5), 129-141doi: 10.5923/j.edu.20150505.02

Yin, R.K. (2014). Case study research design and methods, Thousand Oaks.CA: Sage. 